\title{
TOWARDS A SPORT PROFESSIONALIZATION: THE SITUATION OF THE PLAYER AGENTS IN THE LITHUANIAN FOOTBALL LEAGUE A
}

\author{
Mindaugas Gobikas ${ }^{1}$, Vilma Čingiené ${ }^{1}$, Daniel S. Mason ${ }^{2}$ \\ Lithuanian Academy of Physical Education', Kaunas, Lithuania, University of Alberta ${ }^{2}$, Canada
}

Mindaugas Gobikas. Assistant at the Department of Recreation, Tourism and Sports Management, the Lithuanian Academy of Physical Education. The field of scientific research - sports business, management of professional team sport.

\begin{abstract}
The aim of the research was to identify and evaluate the peculiarities and necessity of a player agent's profession in the Lithuanian sports sector.

The methods of the research: the analysis of a scholarly literature and a standardized interview. 30 Lithuanian Football League A (LFLA) players who did not have a player agent answered the interview's questions.

The majority of the LFLA players do not employ a player agent, however they all recognize the necessity of these professionals in the professional sports industry. Low salaries, the lack of information about player agents and their practice, poor player agents' reputation were identified as the main reasons for not having an agent.
\end{abstract}

Keywords: the work of a player agent, professional sport, Lithuanian Football League A.

\section{INTRODUCTION}

$\mathrm{O}$ ver the past few decades, the European sports system has become increasingly professionalized. For example, there has been a marked shift from a traditional winmaximization approach to profit-maximization in European football and basketball (Gardiner, 2000; Késenne, 2002). The industry has also been affected by globalization and the changes of the political and economic climate of the European Union. Within this context, player agents have emerged as important stakeholders in professional sports. More specifically, football and basketball have become the premier professional team sports in Europe. The FIFA's (the International Football Federation) Champions League tournament has been a marquee event and basketball's Euroleague, organized by the ULEB (the Union of Basketball Leagues), is widely acknowledged as the second to the NBA (the National Basketball Association) in terms of the caliber of play.

Considering historical imperfections of player agents' regulations (Shropshire \& Davis, 2003; Mason \& Slack, 2001) in the North American professional leagues, this paper seeks to explore player agents in contemporary European professional team sports. However, the 
European model offers several characteristics that differentiate it from its North American counterparts. For example, European sports clubs have to operate in different countries and different markets, and major competitions in Europe take place on international level. Sports leagues are comprised of top teams from different countries. As a result, regulation and monitoring of player agents representing players that play in different countries become increasingly difficult. Moreover, questions arise as to which organization or governing bodies should be held responsible for creating regulations and implementing them. In addition, another major issue emerges due to the fact that participating teams come from different countries and different jurisdictional backgrounds. For these reasons, European professional team sport provides a unique site to examine professional agents. Finally, it is still not known the degree to which agents have proliferated in specific contexts in the European sports system. As the industry becomes increasingly commodified, new opportunities for player agents develop, but a greater understanding of this process is needed. To address this issue, this paper examines the Lithuanian Football League A players to identify a potential market for the player agents.

\section{METHODS}

The analysis of an academic literature, a survey and a structural interview's methods were employed during this study. The collection of the empirical data took place from March to April, 2005.

Research participants. The Lithuanian Football League A had 239 officially registered players in the 2005 season. During the first stage of our data collection we gathered the information on all 239 LFLA players regarding whether they had player agents or not. This information was orally obtained through the team management or directly by contacting the players. Only 49 players were using the services of the player agents.

Instruments. To further analyze the issue of a low proliferation of player agents within the Lithuanian Football League A we selected 30 (three from each team) players who were Lithuanians and who had no agent. The selected players were interviewed using a structural interview's method. The respondents were inquired to identify the reasons for not employing player agents, also, they were asked to provide their thoughts on player agents' profession and the advantages (if any) of having player agents. The interview's data was summarized and the implications that form the majority of this article were drawn.

\section{RESULTS}

The following provides descriptive data on the prevalence of player agents in the 2005 Lithuanian football season. All ten teams from the Lithuanian Football League A (LFLA) had players who were using agents' services, suggesting that agents are already prominent stakeholders in this league. Interestingly, it seemed as though agents served a much more prominent role in representing foreign players in this league; teams that had more foreign players on their rosters consequently had more players who were using the services of a player agent (Fig. 1). No foreign players were contracted with the LFLA teams without the help of an agent.

As a result, it could be assumed that, as the number of foreign-born players increases, the number of player agents in the LFLA will also increase. The dynamics of the foreign players participating in the LFLA championship over the last four years shows an ongoing increment (Fig. 2). Since the 2002 LFLA season the number of the foreign players on the team rosters increased fivefold.

The influx of foreign-born players can be partially attributed to the increasing professionalization of the Lithuanian Football League A. In 2003 the Lithuanian Football Federation (LFF) started to license league clubs. To be licensed, clubs had to meet infrastructure, personnel, and financial guaranties. As a result, LFLA clubs developed into more professional organizations in order to compete, employing administrative personnel and becoming more financially viable. As the league became more formalized and professionalized, more foreign football players were willing to come to Lithuania and play for the LFLA teams. To facilitate this process, agents became more involved in league operations.

As has been stated previously, only 49 LFLA players were using the services of the player agents in 2005 (20\%). More importantly, only eight percent of all the LFLA players were Lithuanians who had an agent. This would suggest 
Fig. 1. The proportion of Lithuanian players with an agent and foreign players in the LFLA teams

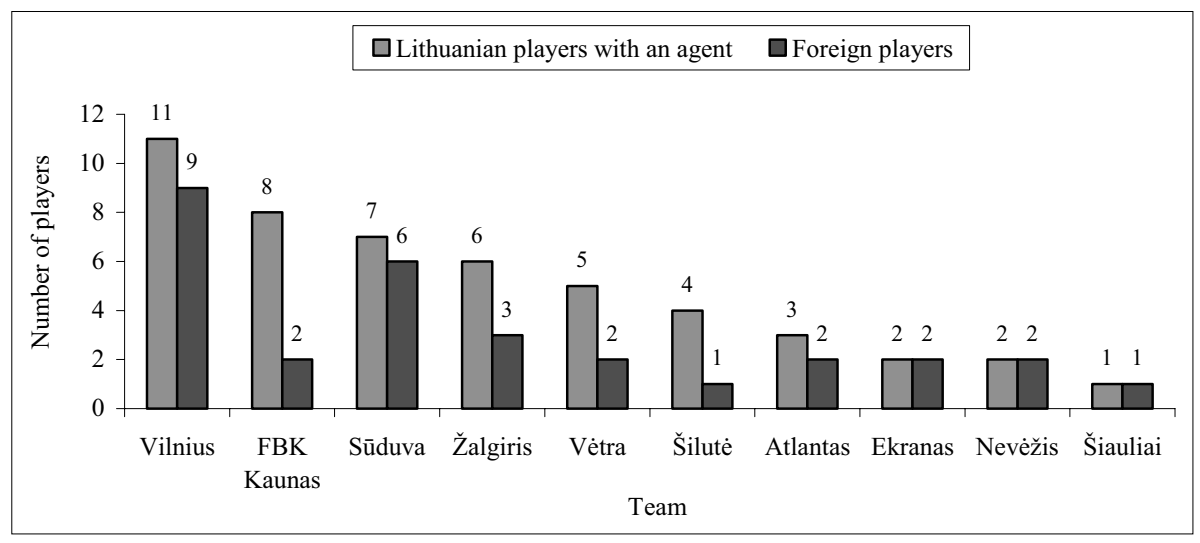

that an opportunity remains for agents to work with Lithuanian players, or that agents' services are more greatly needed by foreign-born players. To address this in greater detail, 30 Lithuanian players (three from each team) who had no agent were interviewed.

During the structured interviews the respondents were asked to share their views on a player agent's profession. The respondents were asked to describe what an agent's duties entailed, and what skills were required to act as an agent. In addition, the interviewees were asked to point out the possible benefits of having a player representative. Finally, probes sight to determine why these players were not employing an agent.

Most of the LFLA players interviewed had a superficial understanding of a player agent - most saw the agent's role as to simply find the client a club to play for, and negotiate the contract for the player. The respondents also indicated that player agents have to be compensated for their work.

As mentioned, the LFLA players who had no player agents were chosen for the interview. Nonetheless, all were aware that a player agent's services are very much in demand, and were able to do a good job for their clients. The most important consideration identified by the players was that an agent knows the football market, has many contacts with the various clubs and, thus, is able to find a club for his or her client. As far as knowledge and educational background requirements were concerned, the respondents indicated that an agent should be a lawyer and know contract and labor laws.

When asked to provide reasons for not employing an agent, the LFLA players pointed out several issues. The first, indicated by all 30 respondents, was that a modest salary precluded hiring an agent. According to the players, the athletes in Lithuania do not earn much money so they could not afford to hire an agent. The respondents supposed that increased salaries would encourage them to hire a professional representative.

In addition, another deterrent to hiring an agent was the fee charged by the agent. Sixty percent of all respondents indicated that an agent's services cost money, thus, incurring additional expenditures. Combined with low playing salaries, the interviewees thought that such expenditure was unnecessary and services could be done on their own.

Almost half of the respondents indicated that a lack of knowledge / understanding of the role and activities of agents was one of the major reasons why agent services were not used. Fourteen LFLA players acknowledged that they simply did not know anything about player agents. In addition, respondents stated that they did not know where to look for the information or whom to ask about it.

Twenty six percent of our respondents indicated that a bad reputation of player agents lead to their decision to not hire one. According to these individuals, there were agents who collected their fee and did not adequately look after their players' interests - at least these were the stories that were circulating.

The LFLA players also indicated that the caliber of pay in their league did not warrant the use of agents. Almost a quarter of all respondents agreed that only the highest caliber players really needed an agent's services. Their high level of play demanded higher salaries and gave them bargaining power, thus allowing players to hire an agent. In addition, the respondents indicated that the player agents themselves were not interested in representing mid-level athletes. According to them, player agents simply do not see the opportunities to earn money in representing a mid-level player. 


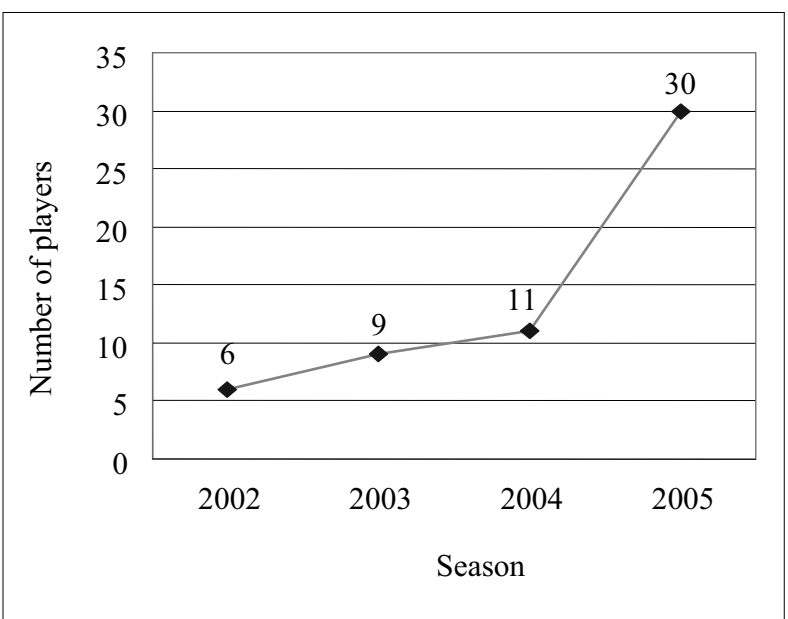

Fig. 2. The dynamics of the foreign players in the LFLA teams

The discussion above suggests a great deal of uncertainty, ambiguity, and a lack of understanding of the role of agents in the LFLA. The LFLA players interviewed provided several contrasting explanations for not having an agent, even though they admit the necessity of player agents. The following section explores the implications of these findings.

\section{DISCUSSION}

Player representatives have emerged in the Lithuanian Football League A, largely because of the arrival of foreign players and an increased professionalization of the league. It is obvious that the increasing professionalization and the skill level of the play have placed new demands on the athletes. Players are now more concerned with their firsthand job - playing football - thus, leaving all the off the field duties to their agents.

However, the results of the interviews described above would suggest that the majority of the Lithuanian LFLA players have a very superficial understanding of what an agent is and the services agents provided. This lack of understanding and information will act as a strong deterrent for the increase in the use of agents by local players; even when some players realized the need of an agent, they did not know where to look for one and hire.

The lack of information is causing a major misinterpretation of player - agent relationships. As the LFLA players have noticed, only the highest paid players can afford to hire representatives. However, the players do not recognize that it is because of a good job performed by their agent the salaries would rise. Players readily admit that agents possess a strong grasp of contract and labor law, and that they have many contacts with the clubs and know the football market. However, players claim that they could do as good of a job themselves, thus, saving an agent's commission. The research has shown that over the long run salaries negotiated by the professional agent are much bigger than negotiated by the players themselves, thus, offsetting commission expenditure (Simon, 1993).

The lack of information is also contributing to a bad reputation of player agents. The LFLA players tend to use word of mouth to gather the information regarding player agents. However, this remains an unsophisticated and potentially problematic means of evaluating an agent's performance. More importantly, players do not recognize what causes such misbehavior and what safeguards can be used to prevent it.

This study would suggest that the market for the player agents in Lithuanian football is still developing. Despite the extensive use of agents by foreign-born players, knowledge and understanding of the player agent's profession in Lithuania is fragmented and contradictory.

\section{CONCLUSIONS}

Using the data gathered from the interviews with the Lithuanian Football League A players, this research has shown that the player agents are a misunderstood part of this sport. As the official FIFA list indicates, there is only one officially licensed players' agent in Lithuania. The players themselves - the main clients of the professional player agents - have not developed a sufficient understanding of a player representative's usefulness. Most of the Lithuanian LFLA players do not have a clear understanding about how professional representation could be obtained and how the benefit of having a professional representative could outweigh the costs. More importantly, the LFLA players recognize that there is no system in place that could help players to arbitrate such problems. 


\title{
REFERENCES
}

Gardiner, S. (2000). The Americanisation of Sports Law? The American and European Models Compared. Internet link: http:web.apu.ac.uk/sportslaw/SG_Americanisation. htm

Késenne, S. (2002). The monopsonistic player labour market in a win-maximising league. European Sport Management Quarterly, 2, 180-187.

Mason, D. S. \& Slack, T. (2001). Evaluating monitoring mechanisms as a solution to opportunism by professional hockey agents. Journal of Sport Management, 15, 107134.

Shropshire, K. \& Davis, T. (2003). The Business of Sports Agents. Philadelphia, PA: University of Pennsylvania Press.

Simon, R. (1993). The Game Behind the Game: Negotiating in the Big Leagues. Stillwater, MN: Voyageur Press.

\section{SPORTO PROFESIONALIZACIJOS LINK: SPORTO AGENTŲ VEIKLOS SITUACIJA LIETUVOS FUTBOLO A LYGOJE}

\author{
Mindaugas Gobikass ${ }^{1}$, Vilma Čingiené ${ }^{1}$, Daniel S. Mason ${ }^{2}$ \\ Lietuvos kūno kultūros akademija ${ }^{1}$, Kaunas, Lietuva, Albertos universitetas ${ }^{2}$, Kanada
}

\section{SANTRAUKA}

Tyrimo tikslas — nustatyti ir apibūdinti sporto agento profesijos pagrisstumą ir šios profesijos veiklos ypatumus Lietuvos sporto sektoriuje.

Atlikta literatūros šaltinių analizè ir standartizuotas interviu. I interviu klausimus atsake 30 (po tris iš kiekvienos komandos) Lietuvos futbolo A lygos (LFAL) žaidèjų, kurie nesinaudoja sporto agentų paslaugomis.

Dauguma LFAL žaidėjų nesinaudoja sporto agentų paslaugomis, tačiau pripažįsta šios profesijos atstovų reikalingumą profesionalų sporte. Pagrindinėmis sporto agentų neturejjimo priežastimis nurodomi menki sportininkų atlyginimai, informacijos apie sporto agentus ir jų veiklą stoka, prasta sporto agentų reputacija.

Raktažodžiai: sporto agento veikla, profesionalų sportas, Lietuvos futbolo A lyga. 